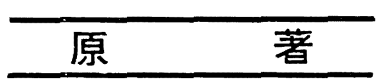

\title{
脳性麻痺患者の頭蓋骨のレ線学的研究
}

\section{Radiological Study on the Cranial Bone of Cerebral Palalysis}

日本医科大学整形外科学教室（主任・斎藤一男教授）

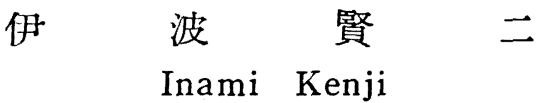

\section{緒言}

脳疾患の矿究は脳の解别, 生理の進展と脳外科の進 歩と相俟つて，最近著しい発展をなしつ」ある。整形 外科領域儿於ても，抆体の機能㜔害の原因をなす脳疾

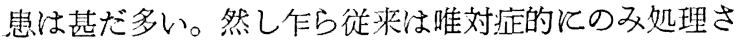
れ，何等抜本的な治䝤対策は講ぜられなかつた。吉に 肢体の機能㜔害を除去, 改善する事を主目的とする所, そこには必ず原因の笁明がなされなけばならない。之 を痛感された柰藤教授, 伊藤講師は先に第23 回日本 整形外科学会総会に於て, 脳疾患と整形外科と題して 脳性麻瘏に関する詳細なる宿題報告をなされ，又教室 佐藤博士は脳性麻痺患者の Pnenmoencephalogramm に就て詳細なる観察を行い，側脳室の掂大を証明し， 且病型別に倒脳室各部の特有の桩大を明示した。而し

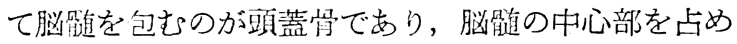
る脳室に言ひか劣れば脳質任器質的变化があれば， そ

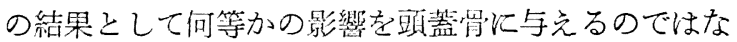

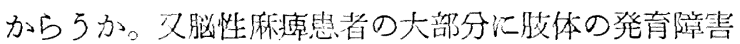
及び知能障害のある事は多くの研究者の認める所であ るが，脳内の分泌器官たる脳下垂体儿何等かの変化が あるのではなかららか, 従つて膊下垂体を容れるとる こ䩪汇导变化がありはしないか。

か」る見地より先人の業䋶を通臨するに，レ線学的

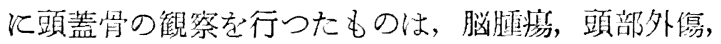
精神病息者等に関して枚举に湶ない程であるが，脳性 麻帛患者汅就いて行つたものは䓕だ少い。

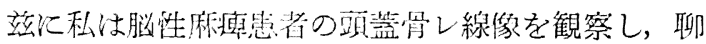
か知見を得たので䇉告し度いと思う。

\section{I. 研 究方法}

\section{1) 研究材料}

斎藤教授，伊藤忠厚博士の定接に従い，脳の機能的 器質的障害による器官活動の異状々態を呈するるのを

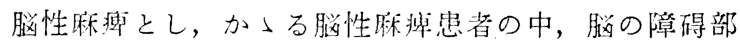
位を異にすると考へられる六型即ち症直を主とする 疗直型，強㴊を主とする強㴊型，両者を湿合せる涅合

型，不随意運動を主とする不随意運動型，弛繯状態を 呈する弛緩型, 器質的変化を認めない神経症型（斎藤 教授，伊藤博士分類）に明らかに属する者 154 例につ いて観察を行つた。

之を年令別飞示すと，第 1 表の通りで，5才以下の

第 1 表

\begin{tabular}{|c|r|}
\hline 例 数 & 例 \\
\hline 5 数 \\
\hline 6 才下 & 50 \\
$6-10 才$ & 39 \\
$11-15 才$ & 15 \\
$16-20 才$ & 11 \\
$21-25 才$ & 11 \\
$26 才 以 上 ~$ & 28 \\
計 & 154 \\
\hline
\end{tabular}

幼児が最も多い。最低年令は 9 ケ月で,最高年命は 60 才である。病型別に見ると，第 2 表の如くで，症直型 が最多数を占め 59 例で, 神経症型は 2 例で最も少 w。

\section{2）レントゲン写重撮影方法}

球管フイルム間距踓を 1 米とし，ブッキーブレンデ は用いない。乙線中心通過線は矢状方向撮影に於て は，眼登上縁と外後頭隆起を結んだ線に平行に，且外 耳孔上 3 粴の点を通る水平面上を通る線とし，侧頭位 撮影に於ては, 左右外斗孔上 3 糎の点を結しだ線とし た。

\section{3）観察竝測定方法}

\section{A. 肉眼的観察}

i）頭蓋繾合：侧面像に於て，㝴状縫合及人字跹 合に就てその出現度を観察した（第1図）。

ii）血管瑇：側面像に於て，小翼签によつて生ず る骨溝の陰影と，中硬脳動脉によつて生ずる骨满の陰 影の出現度を観察した。

iii）後頭隆起：側面像飞於て，外後頭隆起が正常 頭蓋綎曲を超兄て突起状に著しく隆起したものを区別 
第 1 図

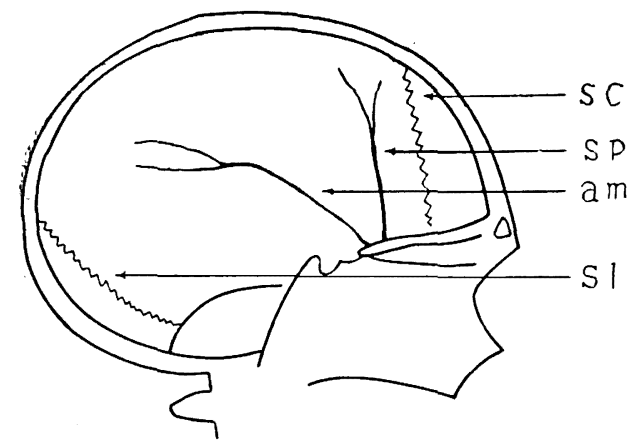

sc 冠状縫合安 $\mathrm{sl}$ 人字繾合

$\mathrm{sp}$ 小翼瑇 am 中硬脳動脈瑇

てその出現度を観察した。

iv）とるこ鞍背の形態：従来の報告は鞍全体の形 態に就て之を観察したものが多いのであるが，私は鞍 背の形態を観察し，之を 3 型に分類した。即ち，鞍の 尖端が鉦状としてレ線像に現れたものを第】型，富士 山型として現れたものを第II型，昆棒状として現れた 第 2 図

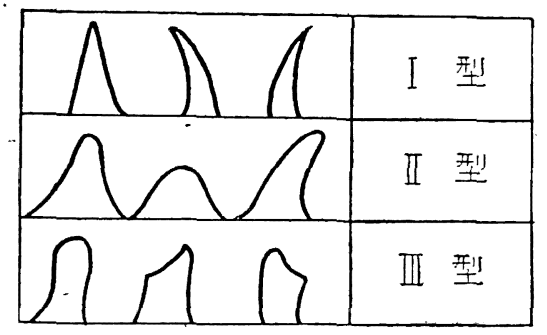

るのを第 III

型とした。

この場合鞍 背の傾㻌度 は考慮に入 犯ず，專ら 形状のみを 問題とし

た。(第 2 図)

B. 計測的観察

i）骨厚：頭蓋骨の厚さは，部位によつて著しい差 があり，一定の部位を定めて測定しなければ比較考察 の対象として船意味である事は諭を俟たない。従つて 先人の測定部位に撤ひ，側面像に於て，大泉門より前 方 3 糎の部位にに於てえの厚さを測定した。

ii) 頭蓋縦径及横径：絴径は，侧面像飞於て眼筑上
縁と, 外後頭隆起とを結んだ距離とし, この際外後頭 隆起が異状に突出したものをも緃径の中に含ませた。 横径は前後像に於て計測し, 最子距離の長いものを 取つて横径とした。即ち，横径は最大横径である。

iii）とるこ鞍：とるこ鞍の計測的研究は各方面か らなされ，計測法も種々あるが，私は縦径と深さの測 定には，最も広く利用されてるる高木教授の方法を用 いた。之は従来の䂨究成績と比較検討するのに都合が よいと思つたからである。又とるこ鞍の形状の如何に 不拘その容積の絶対値を知る為には，面積を知る事が 必要だと思い，プラニメーターによる面積測定をも併 せ行つた。測定方法としては，レ線フイルムをシャウ カステン上に置き,フイルムの上に薄い硝子板を重㸚, とるこ靶の影像をパラフイン紙に複写し, 径長測定は 第 3 図の如く 4 径に就て計測を行つた。

第 3 図

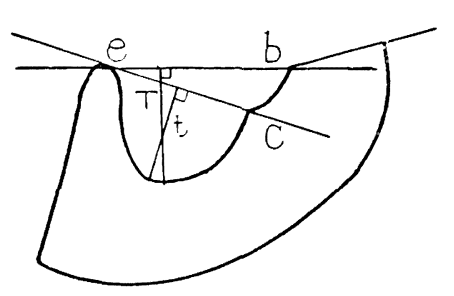

b 出形骨緑

c 鞍結節

e 下垂体窗が斜台 線飞移行する点

$\mathrm{T}$ 下垂体底より $\mathrm{b}$ e に至る最大垂 線

t 下垂体底:上り $c$ e に至る最大線

面積測定は，前舐複写像をプラニメーターを用い て繰返し20 回前後測定し誤差の茫しいと思はれるも のを除きそその平均値を以て值とした。

I1. 研 究, 成 績

\section{1）肉眼的観察による成績}

i) 頭蓋縫合: 冠状綘合 (sc と唂记) 及人字絽合 （s1 と略記）の出現率は，第 3 表の如くである。骨縫 合は年令の進むと従い閉鎖するものであるから，一般 に年長者に於て出現率が減少する事は当然考兄られる 所で,脳性麻掂腎者に於てもこの傾向は認められるが， 確然たるものではない。

田村氏は 128 例の正常者の頭蓋描写図に就て研究報 第 3 表 頭蓋縫合及血管溝出現率

\begin{tabular}{|c|c|c|c|c|c|}
\hline 年 & sc & sl & $s p$ & $a m$ & 例 \\
\hline 5 才以下 & $64.0 \%(32)$ & $86.0 \%$ & $20.0 \%(10)$ & 26.0 & 50 \\
\hline $6-10$ 才 & 46.15 & 79.48 & $33.3 \%$ (13) & $33.3,0 \quad(13)$ & 39 \\
\hline $11-15$ 才 & $53.3 \%$ ( 8) & $66.6 \%(10)$ & $33.3 \%(5)$ & $20.0 \%(3)$ & 15 \\
\hline 16 一 20 才 & $36.4 \%(4)$ & $63.6 \%(7)$ & $45.5 \%(5)$ & $36.4 \%(4)$ & 11 \\
\hline $21-25$ 才 & $63.3 \%(7)$ & $90.9 \%(10)$ & $18.2 \%(2)$ & $54.5 \%$ (6) & 11 \\
\hline 26 才以上 & $35.7 \%$ & $71.4 \%(20)$ & $21.4 \%(6)$ & $50.0 \%$ (14) & 28 \\
\hline
\end{tabular}

（括弧内は実数を示す） 
告したが，私の例と田村氏例とを比軹するに，田村氏 例よりはるか江少い出現率を示している。即ち sc は 田村氏例に於ては 15 歳以下の钼察では 94.4\%, 16 歳以上 $47.30 \%$ であるのに対し, 私の例に於ては, 最 高が 5 藏以下の $64 \%$, 最低は 26 歳以上の $35.7 \%$ で はるかに少い。

si は田村氏例に於ては, 15 藏以下 $100 \%, 16$ 歳以 上 $95.5 \%$ で, 年少者に於ては $100 \%$ の出現率を示 し，年長者に於ても殆ど出現を認めている。私の例に 於ては，21-25 歳の 99.9\%の外は各年令屏に於て $66.6 \%-86 \%$ の出現しか認めない。

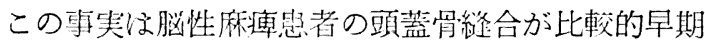
に癒合する事を意味するものと思方れ，精神発育制止 症者の頭罜骨綘合が早期に癋合する事があるとい5成 書の記載と一致するるので興味ある結果である。

ii）血管溝 : 血管溝の出現率は第 3 表の如くで, 年 令の增加と共に大となる傾向が認められるが，之も田 村氏例と比較するときは，著しく出現率は低下してい る。即ち sp は，田村氏例に於ては 15 歳以下 83.3 。，16 藏以上 $96.4 \%$ であるに対し,私の例に於ては 各年令酋共 $50 \%$ 以下である。

am 飞就て云5と, 田村氏例では, 15 歳以下 16.7 $9 \dot{0}, 16$ 藏以上 $71.8 \%$ で, 私の例では 5 歳以下 $26 \%$, 6-10歳 33.3\%，11-15歳 20\%で年少者に於て低 率である事は一致するが，16 歳以上の酋では，21一 25 于の $54.5 \%$ が最高で,之は田村氏例よりはるかに 少い。

iii）後頭隆起：脳疾患特泊㾰及精神病虫者の頭 蓋骨レ線像とは，頭蓋骨の汎発性肥厚が証明せられる と成書に記載せられ, Virchow, Rokitansky, Griesnger, Giacomini, Humphrey 等の病理学者も之を 唱導し，特にChiari は之に注目し，Rachitis や炎症 性, 久は老人性のものとは全く関係のない独立した

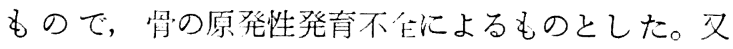
Reiche 其他は脳性小児麻淿患者のレ線像に頭蓋骨の 骨增殖を見たと云つている。

そこで私は頭門冠の一部である外後頭隆起に着目 し，その結果交期待して観察を試みたのであるが，特 に意義を附する程の結果は得られなかつた。即ち観察 結果は第 4 表に示す如くで, 钼察総数 154 例中異状隆 起を熟めたもの 151 例で, その大部分は 20 歳以上で あり, 20 歳以下の者では, 僅かに 1 例に於て認めた に過きない。

iv) とるこ鞍背の形態：とるこ鞍北形態の観察結
第 4 表

\begin{tabular}{|c|c|c|}
\hline & 隆起出現数 & 観 察 例 数 \\
\hline 5 才以下 & 1 & 50 \\
$6-10$ 才 & 0 & 39 \\
$11-15$ 才 & 0 & 15 \\
$16-20 才$ & 0 & 11 \\
$21-25$ 才 & 4 & 11 \\
26 才以上 & 10 & 28 \\
\hline
\end{tabular}

第 5 表

\begin{tabular}{|c|c|}
\hline I 型 & $21(18.690)$ \\
\hline II 型 & $66\left(58.40_{0}^{\circ}\right)$ \\
\hline III 型 & $26\left(23.090^{\circ}\right)$ \\
\hline
\end{tabular}

果は第 5 表の如くで，第 II 型に属するものが最も 多く,はつきり観察し得 た 113 例中 66 例 $(58.4$ ○)を占め, I , III 型に 属するものは略同数で 21 例 $(18.6 \%), 26$ 例 $(23.0 \%)$ である。

正常者に就ての観察がない為この結果について比較 検討はできないが，殆ど正常者と差がないと認められ

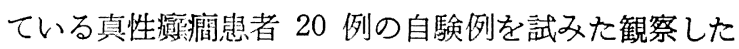
結果は, II 型 11 例 $(55 \%)$, I 型 3 例 $(15 \%)$, II 型 6例 $\left(300^{\circ}\right)$ で殆ど前者と一致する。従つて本観察結 果のみで判断すれば，脳性麻席患者のとるこ鞍背の形 態には何等特有のものはないと云克るが, 佾研究の余 地を残している。

\section{2) 計測成績}

i）骨厚：1）白痴及精神病㦝者の頭蓋骨飞於て 沉発性肥厚が証明される事はVirchow 其他の病理学 者の認める所にして，又 Reiche 其他は脳性小児麻渒 㭧者のレ線像に於て骨増殖を認めると云つている事 は，1）の iii）に於て述べた通りであるが，私は個々 の症例はさて招き 154 例飞就て計測した結果に就き統 計的考察を試みた。結果は第 6 表に示す如くで, 年令 別に見ると, 確実に年令の増加に正比例して厚さを増 している。今之を田村氏の正常例と比較すると, 田村 氏例 15 歳以下 $4.3 \mathrm{~cm}(4.04 \mathrm{~cm}), 16$ 歳以上 $7.0 \mathrm{~cm}$ $(6.6 \mathrm{~cm})$ （括弧内は条件換算值にして換算法は後記 す）に比較して殆ど近い値を示している。而して発育 過程より見ると，16--20 歳に於て稍増大の度が大き い。

ロ）骨厚と脳圧との関係 頭蓋骨の沉発性肥厚の 原因に就いては適当なる説明は未だにないのである が，研究者の意見を綜合すると，(1) 脳髄が小さくな る為に生じた空隐を充す為に代儥的に肥厚する，(2) 慢性脳圧克進の結果, (3) 脳疾㭧に因る発育障害によ 
第 6 表

\begin{tabular}{|c|c|c|c|}
\hline & 最 大 横 径 & 粉 & 骨 \\
\hline 5 才以下 & $146.3 \pm 8.8$ & $159.6 \pm 13.1$ & $3.28 \pm 0.88$ \\
\hline $6-10 才$ & $149.87 \pm 9.1$ & $169.4 \pm 21.8$ & $4.13 \pm 1.07$ \\
\hline $11-15$ 才 & $162.85 \pm 7.5$ & $172.5 \pm 10.2$ & $4.48 \pm 1.24$ \\
\hline $16-20 才$ & $165.68 \pm 6.7$ & $190.2 \pm 10.9$ & $5.9 \pm 1.18$ \\
\hline $21-25$ 才 & $157.5 \pm 8.7$ & $192.05 \pm 12.3$ & $6.64 \pm 1.56$ \\
\hline 26 才以上 & $164.28 \pm 10.0$ & $195.8 \doteq 13.7$ & $6.57 \pm 1.79$ \\
\hline
\end{tabular}

(單位 $\mathrm{mm}$ )

る等の事が云われている。而して田村氏は 29 例の脳 睡揚患者（脳下垂体腫序以外）を検し，脳圧々骨厚と は平行しないと報告している。然らば綏性麻瘦宫者に 於ては如何。

私は自験例中確実なる記載のあるもので，号泣，騒 暴等に依つたと思われる不安定なものを除き $300 \mathrm{~mm} /$ $\mathrm{H}_{2} \mathrm{O}$ (坐位) 以上のものと, $300 \mathrm{~mm} / \mathrm{H}_{2} \mathrm{O}$ (坐位) 以 下のものについて検したのであるが，その結果は第 7 表の如くである。即ち各年令層共に $300 \mathrm{~mm} / \mathrm{H}_{2} \mathrm{O}$ 以

第 7 表

\begin{tabular}{|c|c|c|c|}
\hline 年 令 & 膇 & 骨厚の平均値 & 例数 \\
\hline \multirow{2}{*}{5 少 } & \multirow{2}{*}{$\begin{array}{l}300 \mathrm{~mm} / \mathrm{H}_{2} \mathrm{O} \text { 以上 } \\
300 \mathrm{~mm} \mathrm{H}_{2} \mathrm{O} \text { 以下 }\end{array}$} & $3.17 \mathrm{~mm} \pm 0.206$ & 9 \\
\hline & & $3.36 \mathrm{~mm} \doteq 0.45$ & 7 \\
\hline \multirow{2}{*}{$6-$} & \multirow{2}{*}{$\begin{array}{l}300 \mathrm{~mm} / \mathrm{H}_{2} \mathrm{O} \text { 以上 } \\
300 \mathrm{~mm} / \mathrm{H}_{2} \mathrm{O} \text { 以下 }\end{array}$} & $3.81 \mathrm{~mm} \pm 0.322$ & 13 \\
\hline & & $4.59 \mathrm{~mm} \pm 0.31$ & 11 \\
\hline \multirow{2}{*}{$\begin{array}{l}\text { 16才 } \\
\text { 以上 }\end{array}$} & \multirow{2}{*}{$\begin{array}{l}300 \mathrm{~mm} / \mathrm{H}_{2} \mathrm{O} \text { 以上 } \\
300 \mathrm{~mm} / \mathrm{H}_{2} \mathrm{O} \text { 以下 }\end{array}$} & $6.56 \mathrm{~mm} \pm 0.339$ & 18 \\
\hline & & $7.5 \mathrm{~mm} \pm 1.05$ & 4 \\
\hline
\end{tabular}

上のものは以下のものより骨厚は小である。

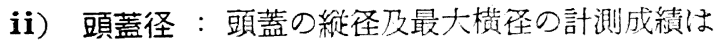
第 6 表の如くで, 之も年令の堌加と略正比例して增加 しているが，最大横径は 11-15 歳に於て急に発育を 増大し略成人と同等の值になつて方り, 紌经は 16-20 歳に於て生長の度著しく成人の域に迄達している事は 注目に值する。

iii）とるこ鞍：レ線像に表れたとるこ䩳售の大い さは真の脳下垂体の大いさを表するのではないるする 学者むある。Reinert 等がそれである。然し両者の平 行を認める学者も多い。即ち, Cignolini は, とるこ 鞍の Prophil に於てその直径の 80 。 が脳下垂体の 直烽棂ると无つている。Haas は 1925 年 Forts chritt auf dem Gebiet der Rontgenstrahlen Bd. 33 に於て，脳下垂体とレ線像上のとるこ鞍の大いさ
に就てその研究成績を発表している が，臨床的に这下垂体が大であると 想像せられた 39 例中， 31 例は明ら かにとるこ鞍のレ線像が正常者より 大であつたと云い，とるこ鞍のレ線 映像が脳下垂体の大いさを可成り正 しく反影すると云つている。

1932 年 Bokelmann は新鮮頭蓋 のとるこ鞍を水銀法に依り, 彼の sog. mediane Sellaprophilfläche を測定し，一般に小なるとるこ鞍は小なる脳下垂体を， 大なるとるこ鞍は大なる脳下垂体を有する事が分つ た，乙報告している。又 1939 年 Ottavani は，屍体 70 例飞就て次の様な研究報告を行つた。

即ち, 成人脳下垂体の大いさは $0.3 \sim 1.3 \mathrm{ccm}$ 平均 $0.6 \mathrm{ccm}$ であり, 之を容れるとるこ鞍の容積は 0.8 $2.0 \mathrm{ccm}$, 平均 $1.2 \mathrm{ccm}$ で大凡 2 倍である。尤も脳下垂 体の大いさは略平均しており，0.5 ccm 内外のものが 大部分であるが，とるこ鞍の容積には極めて大小の差 が甚しい。従つてレ線像上測定した值は必ずしも脳下 垂体の真の大いさと比例しない。然し乍ら脳下垂体が 腫大しても向 $0.6 \sim 0.7 \mathrm{ccm}$ 前後の余裕が Perihypophysärraum として貽されており, 従つてその大いさ が倍加してもとるこ鞍本来の容積には裹も変化を及ぼ さないであろうと述べている。

之を要するに, 脳下垂体の真の大いさとレ線像上の とるこ鞍の大いさとの関係については, 佾残された問 題が多いのであるが，大体に於て，全く無相関ではな いという事はできよう。

私は脳性麻源の原因を脳下垂体ホルモンに求めよ5 とするものではないが，乙線像上のとるこ鞍の消息如 何を検索すべくとるこ鞍の大いさを测定し検討を試み た。

测定は高木教授法に依る各烃の計測と, プラニメー ターに依る面積側定を行い次の結果を得た。結果は第 8 表の如くで, 大体に於て各㹩とも年令の増加と共に 増大の傾向が見られるが, 11-15歳の間に於て稍大き い增加を示しているのが注目され，既に骨の最終発育 年令と見られる 26 歳以上の值と略同值を示している。 宇田川, 高梨氏等は健康小児 32 例の観察に於て, と るこ鞍の発青は 1-5 歳の間に最もよく発育すると報 告しているが，私の例に於ては 11-15 藏の間に稍急 な発育をする傾向を示している。

面積に就ては第 8 表の如くで, 規則正しく年令に平 
第 8 表

\begin{tabular}{|c|c|c|c|c|c|c|}
\hline 年 & $\mathrm{be}_{\mathrm{mIn}}$ & $c e_{m i n}$ & $T_{m m}$ & $t_{\mathrm{mm}}$ & 面 積 $\mathrm{ccm}$ & 例 \\
\hline 5 才以下 & $14.29 \pm 2.8$ & $9.2 \pm 1.56$ & $7.32 \pm 1.22$ & $5.72 \pm 1.37$ & $0.722 \pm 0.228$ & 50 \\
\hline $6-10$ 才 & $14.6 \pm 3.44$ & $8.6 \pm 2.24$ & $7.72 \pm 1.35$ & $6.59 \pm 1.24$ & $0.768 \pm 0.255$ & 39 \\
\hline $11-15 才$ & $16.6 \pm 2.48$ & $10.1 \pm 1.97$ & $9.4 \pm 1.72$ & $7.52 \pm 1.24$ & $0.92 \pm 0.142$ & 15 \\
\hline $16-20$ 才 & $14.46 \pm 3.36$ & $9.0 \pm 1.6$ & $9.0 \pm 1.1$ & $6.27 \pm 1.42$ & $0.99 \pm 0.13$ & 11 \\
\hline $21-25$ オ & $14.1 \pm 3.4$ & $10.45 \pm 2.36$ & $9.18 \pm 1.71$ & $7.72 \pm 1.47$ & $1.04 \pm 0.297$ & 11 \\
\hline 26 才以上 & $16.1 \pm 2.94$ & $10.29 \pm 0.75$ & $9.14 \pm 2.18$ & $7.7 \pm 1.86$ & $1.09 \pm 0.265$ & 28 \\
\hline
\end{tabular}

行して增大しているが，知張り 11-15 歳の間沦於て 稍増大の度を增しているのは，各径の場合と同様の結 果となり前述の事実と一致するるのである。

次に私の測定結果と先人の測定結果とを比較すると 第 9 表の通りである。然し乍ら之は撮影条件が異るの で，そのま〉比較するのは無意味である。そこで私は 次の如き条件換算を行つた。

第 9 表の 1 各径の比較（成人）

\begin{tabular}{|c|c|c|c|c|c|}
\hline 測定者 & $\mathrm{be}_{\mathrm{mm}}$ & $\mathrm{ce}_{\mathrm{min}}$ & $T_{\mathrm{mm}}$ & $t_{\mathrm{mm}}$ & 年令 \\
\hline 高 木 & 16.3 & 14.6 & 2.9 & 10.6 & 成人 \\
\hline 安 田 & 15. & 11 & 10.2 & 8.9 & 成人 \\
\hline 田 村 & 17.3 & 12.9 & 11.2 & 6.8 & 成人 \\
\hline \multirow{3}{*}{ 伊 波 } & \begin{tabular}{|}
14.5 \\
\pm 3.36
\end{tabular} & $\begin{array}{l}9.0 \\
\pm 1.6\end{array}$ & $\begin{array}{l}9.0 \\
\pm 1.06\end{array}$ & $\begin{array}{l}6.3 \\
\pm 1.42\end{array}$ & $6-$ \\
\hline & $\begin{array}{l}14.1 \\
\pm 3.4\end{array}$ & $\begin{array}{l}10.5 \\
\quad \pm 2.36\end{array}$ & $\begin{array}{l}9.2 \\
\stackrel{ \pm}{ \pm} 1.7\end{array}$ & $\begin{array}{l}7.7 \\
\pm 1.47\end{array}$ & $21-$ \\
\hline & $\begin{array}{l}16.1 \\
\quad \pm 2.94\end{array}$ & $\begin{array}{l}10.3 \\
\quad \pm 0.7\end{array}$ & $\begin{array}{l}9.1 \\
\quad \pm 2.18\end{array}$ & $\begin{array}{l}7.7 \\
\pm 1.86\end{array}$ & $26 t$ \\
\hline
\end{tabular}

第 9 表の 2 各径の比較 (15才以下)

\begin{tabular}{|c|c|c|c|c|c|}
\hline 測定者 & $\mathrm{be}_{\mathrm{min}}$ & $\mathrm{e}_{\mathrm{m} m \mathrm{~m}}$ & mm & $\mathrm{t}_{\mathrm{mm}}$ & + \\
\hline 田 村 & 16. & 11 & 9.0 & 7.6 & 15才 \\
\hline \multirow{3}{*}{ 伊 波 } & $\begin{array}{l}14.3 \\
\pm 2.8\end{array}$ & $\begin{array}{l}9.2 \\
\pm 1.55\end{array}$ & $\begin{array}{l}7.3 \\
\quad \pm 1.22\end{array}$ & $\begin{array}{l}5.7 \\
\quad \pm 1\end{array}$ & 式 \\
\hline & $\begin{array}{r}14.6 \\
\pm 3.44\end{array}$ & $\begin{array}{l}8.6 \\
\pm 2.24\end{array}$ & $\begin{array}{l}7.7 \\
\quad \pm 1.35\end{array}$ & $\begin{array}{l}6.6 \\
\pm 1.24\end{array}$ & $6-$ \\
\hline & $\begin{array}{l}16.6 \\
\pm 2.48\end{array}$ & $\begin{array}{l}10.1 \\
\quad \pm 1.97\end{array}$ & $\begin{array}{l}9.4 \\
\quad \pm 1.72\end{array}$ & $\begin{array}{l}7.5 \\
\pm 1.24\end{array}$ & $11-$ \\
\hline
\end{tabular}

高木氏 ブツキイブレンデを使用せず， 焦点フイルム間距離 $60 \mathrm{~cm}$

安田氏 ブッキイブレンデを使用せず, 焦点フイルム間距離 $50 \mathrm{~cm}$

田村氏 ブツキイブレンデを使用， 焦点フイルム間距離 $68 \mathrm{~cm}$

汽波 ブッキイブレンデを使用せず， 焦点フイルム間距離 $100 \mathrm{~cm}$
今とるこ鞍とブツキイ表面迄との距離を $7 \mathrm{~cm}$ と見 做し（ブッキイとフィルム迄との距離は略 $3 \mathrm{~cm}$ ), 私 の条件で測定せる值を $a$ とし, 高木教授, 安田氏, 田 村氏の条件で測定した值を各々 $b, c, d$ とすれば， $a$ ， $b, c, d$ の関係は次の如くになる。

$$
\begin{aligned}
& \frac{a}{b}=\frac{100}{93} \times \frac{58}{68}=0.94 \\
& \frac{a}{c}=\frac{100}{93} \times \frac{43}{50}=092 \\
& \frac{a}{d}=\frac{100}{93} \times \frac{53}{60}=0.95
\end{aligned}
$$

従つて高木教授，安田氏，田村氏の測定值を私の撮 影条件の下飞行つて得らるべき值飞換算を行つた結果

\begin{tabular}{|c|c|c|c|c|c|}
\hline 測定者 & $\mathrm{be}_{\mathrm{mu}}$ & $\mathrm{ce}_{\mathrm{mm}}$ & $T_{m m}$ & $t_{\mathrm{mm}}$ & 年令 \\
\hline 高 木 & & & 16 & 10.1 & 戎人 \\
\hline 安 田 & & & & 3.2 & ¿ \\
\hline 田 村 & 16 & 1 & 10 . & 6.4 & 或人 \\
\hline \multirow{3}{*}{ 伊 波 } & $\begin{array}{c}14.5 \\
\pm 3.36\end{array}$ & $\begin{array}{l}9.0 \\
\pm 1.6\end{array}$ & $\begin{array}{l}9.0 \\
\pm 1.06\end{array}$ & \multicolumn{2}{|c|}{$\begin{array}{l}6.3 \\
\quad \pm 1.42 \quad 20 才\end{array}$} \\
\hline & $\begin{array}{c}14.1 \\
\pm 3.4\end{array}$ & $\begin{array}{c}10.5 \\
\pm 2.36\end{array}$ & $\begin{array}{l}9.2 \\
+1.7\end{array}$ & \multicolumn{2}{|c|}{$\begin{array}{l}7.7 \quad 21- \\
\pm 1.47^{2} \quad 25\end{array}$} \\
\hline & $\begin{array}{c}16.1 \\
\pm 2.94\end{array}$ & $\begin{array}{l}10.3 \\
\pm 0\end{array}$ & $\begin{array}{l}9.1 \\
+2.18 \\
\end{array}$ & 7.7 & \\
\hline
\end{tabular}
は第 10 表の如くになる。

第 10 表の 1 各径換算値の比較（成人）

節 10 表の 2 各径算換値の比較（15才以下）

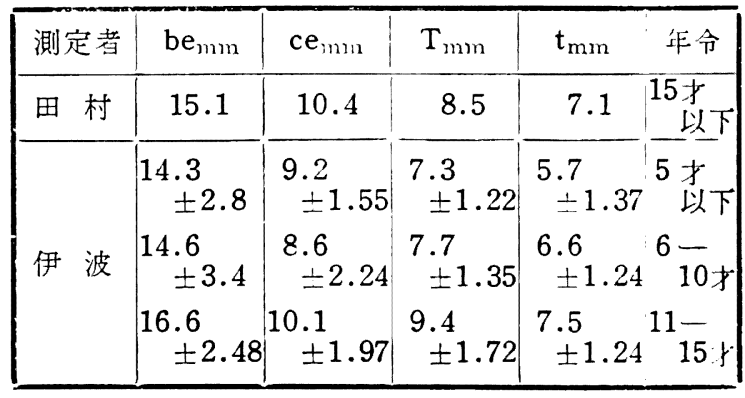

即ち, 成人に於ては 21-25 歳の值が安田氏の犆上 略近い值を示し， 26 瓷以上が田村氏の值と稍等しく， 
高木教授の值よりは, 26 歳以上の be を除いて何れも 小なる值を示している。

之を要するに，一般に成人に於ては正常者のとるこ 鞍と殆ど差がないと云える。

15 歳以下に就て見るに, 10 歳以上の值は何れる田 村氏の值より小なる值を示しているが，11-15 歳に なると稍大きい值に変つてきている。従つて脳性麻痺 患者のとるこ鞍は 10 歳迄はその発育が正常者より遅 れ，11-15 歳の間に稍急速な発育をなし，成人になる と正常者と略同等の大いさか，或は稍小となるとるこ 鞍として完成されるるのと思われる。

\section{3）小括}

以上の通り肉眼的観察と計測的観察を行つたのであ るが，之を総括すると次の通りである。

(i) 脳珄麻瘦㭧者の頭蓋縫合泟常人と同様に一 般に年令の増加と共に減少する傾向が認められるが, 正常人程判然としない。而して正常人よりも出現率は はるかに少い。

（ii）後頭隆起に就いては, 20歳以上の者に於ては 39 例中 15 例を認めたが，20 歳以下では 115 例中僅 かに 1 例を認めたに過ぎず，特に意義は附し難い。

（iii）イ）骨厚は確実に年令の増加洋つて大とな つており,且正常人のそれと略近い值を示しているが， 16一20 歳の間に於て急に発育の度を増す。

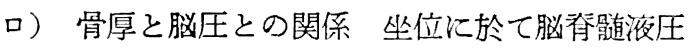
$300 \mathrm{~mm} / \mathrm{H}_{2} \mathrm{O}$ 以上のものと, $300 \mathrm{~mm} / \mathrm{H}_{2} \mathrm{O}$ 以下の のとを比較した結果は, 前者の方が後者より骨愿は小 である。即ち圧の高い方が薄い。

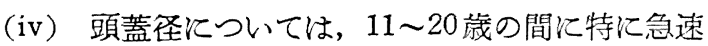
な発青を示す。即ち, 横径は 11〜15 歳の間泟最すよ く発育し縦径は 16 20 歳の間に生長が著しい。

（v）とるこ鞍 1）各経諒て言5と，生長が完 成したと思われる年令になると正常人と略同等の值 か，或は稍小なる值を示しているが，発育過程からみ ると 11〜15 藏の間と最もよく発育するものと思われ る。

口）面積は規則正しく年令に平行して増大してい るが, 各経と同じく 11 15 歳の間泛於て稍増大の度 を増している。

1）ロ）の事実は正常小归のとるこ鞍は 1〜5 歳 の間に最もよく発育すると言5先人の報告と異るもの である。

(vi）とるこ鞍背の形態は，之を概ね三型飞分類す ることができる。即ち，尖端が鍾状をなするの( I 型)，
尖端が富士山型をなするの（II 型），棍棒状をなすも の（型），の三型である。而して【型属するるの が過半数を占め $58.4 \%$ であり，I，型は略同数で, I 型 $18.6 \%$ ，【型 $23.0 \%$ である。

\section{III. 脳性麻瘦患者病型别観察}

前章迄に各項目に亘り観察, 計測した結果について 考察を試みたのであるが，次汇斎藤教授，伊藤博士の 分類による脳性麻㾪六型についての病型別観察を行つ た結果は次の通りである。

1）頭蓋縫合，血管满

頭蓋縫合, 血管溝の各型別出現率は, 第 11 表の如 くで, 頭蓋縫合は冠状縫合, 人宇縫合共に痤直型に出 現率が多く，不随運動型沙い傾向があるよ5に思わ れるが，特に意義を附する程のものとは思われない。

第 11 表

\begin{tabular}{|c|c|c|c|c|c|c|}
\hline 病 & 型 & 郡号 sc & sl & $\mathrm{sp}$ & am & 利娄 \\
\hline 瘠＼cjkstart直 & 型 & SP. $\begin{array}{l}61 \\
(36)\end{array}$ & $\begin{array}{r}91.5 \\
(54)\end{array}$ & 25. & $\begin{array}{l}42.3 \% \\
(25)\end{array}$ & 59 \\
\hline 强 用 & 型 & Rig. $\begin{array}{c}55.50 \\
(10)\end{array}$ & 672.29 & 811. & & 1 \\
\hline $\begin{array}{l}\text { 癄直強 } \\
\text { 混合 }\end{array}$ & $\begin{array}{l}\text { 㹈 } \\
\text { 型 }\end{array}$ & $\begin{array}{l}\mathrm{SP}+{ }^{40.9} \\
\mathrm{Rig}(18)\end{array}$ & $\begin{array}{r}75^{\circ} \\
(33)\end{array}$ & (1) & $\begin{array}{c}31.8 \\
(14)\end{array}$ & 4 \\
\hline $\begin{array}{ll}\text { 丕 } & \text { 随 } \\
\text { 運 } & \text { 動 } \\
\end{array}$ & 型 & EX. $(6)$ & $\begin{array}{r}657.80 \\
\quad(11) \\
\end{array}$ & $\begin{array}{r}31.5 \\
\quad(6) \\
\end{array}$ & $\begin{array}{c}31.50 \\
(6)\end{array}$ & 15 \\
\hline 經 & 型 & h. $\begin{array}{r}58.3 \\
(7)\end{array}$ & $\begin{array}{r}75 \% \\
(9)\end{array}$ & $\begin{array}{r}33.30 \\
(4)\end{array}$ & $\begin{array}{r}25 \\
(3)\end{array}$ & 12 \\
\hline 甲 & {[} & $\begin{array}{l}50 \text { (1) } \\
(1)\end{array}$ & $\begin{array}{c}500 \\
(1)\end{array}$ & $\begin{array}{l}50 \\
(1\end{array}$ & $\begin{array}{l}50 c_{5}^{c} \\
(1)\end{array}$ & \\
\hline
\end{tabular}

（括弧内は実数を示す）

血管溝については向更各型間汸於ける特異な現祅方 とい5ものはない様思われる。

\section{2）骨厚，頭蓋径}

骨原，頭蓋径の各型別計剆值の平均值は第 12 表の 如くである。

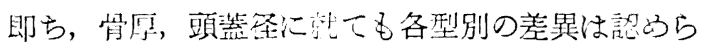
れない。

3）とるこ鞍

(i) とるこ鞍の各径及面積の計測值の各型別平均 值は第 13 表の通りで, 之も各型別の差異は認的られ ない。

(ii) とるこ鞍背の形態 とるこ鞍背の形態は大略 3 型に分類できる事は前述の通りであるが，之を各型 別に分類した結果は，第 14 表の如くである。即ち， 鞍背の型別から見ると第 II 型洋属するるのが最も多く $58.4 \%$ を占めてみる。病型別見ると,第 I 型汇属す るものの中では混合型が多く $33.3 \%$ を占め, 第 II 型 では痤直型が $43.9 \%$, 次いで混合型 25.7\%, 次いで 


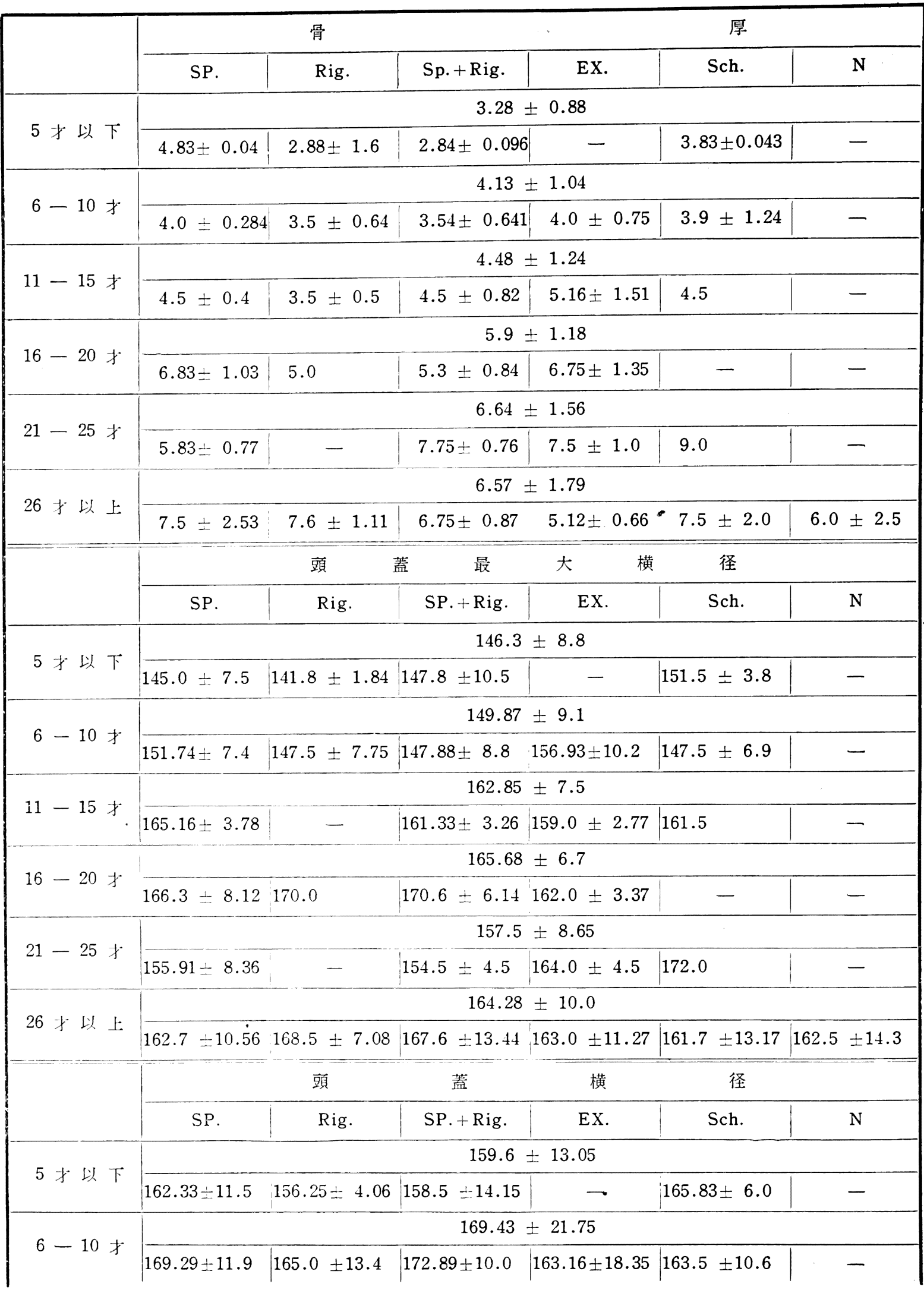




\begin{tabular}{|c|c|c|c|c|c|c|}
\hline \multirow{2}{*}{$11-15 才$} & \multicolumn{6}{|c|}{$172.5 \pm 10.2$} \\
\hline & $170.3 \pm 14.31$ & - & 168.0 & $\pm 3.94 \quad 178.8 \pm 19.18$ & 168.0 & - \\
\hline \multirow{2}{*}{$16-20 \nsucc$} & \multicolumn{6}{|c|}{$190.23 \pm 10.85$} \\
\hline & $185.3 \pm 12.8$ & 202.0 & 183.6 & $\pm 12.78 \mid 196.0 \pm 8.13$ & - & - \\
\hline \multirow{2}{*}{$21-25 才$} & \multicolumn{6}{|c|}{$192.05 \pm 12.25$} \\
\hline & $197.3 \pm 10.4$ & 一 & 181.0 & $184.0 \pm 15.0$ & 201.0 & - \\
\hline \multirow{2}{*}{26 才以上 } & \multicolumn{6}{|c|}{$195.8 \pm 13.7$} \\
\hline & $189.3 \pm 23.1$ & $206.83 \pm 13.07$ & 195.8 & \begin{tabular}{l|l|l} 
\pm 16.36 & $190.25 \pm 13.34$
\end{tabular} & $201.25 \pm 10.25$ & $188.75 \pm 3.25$ \\
\hline
\end{tabular}

第 13 表 の 1

\begin{tabular}{|c|c|c|c|c|c|c|c|c|c|c|c|}
\hline \multirow{2}{*}{$\begin{array}{c}\text { とるこ鞍径 } \\
\text { 年令区分 }\end{array}$} & \multicolumn{5}{|c|}{ be } & \multicolumn{6}{|c|}{$\mathrm{ce}$} \\
\hline & SP. & \begin{tabular}{l|l|} 
Rig. & SP. \\
\end{tabular} & EX. & Sch. & $\mathrm{N}$ & SP. & Rig. & $\begin{array}{c}\text { SP.+ } \\
\text { Rig. }\end{array}$ & EX. & Sch. & $\mathrm{N}$ \\
\hline \multirow{2}{*}{$0-5$ 才 } & \multicolumn{5}{|c|}{$14.29 \pm 2.8$} & \multicolumn{6}{|c|}{$9.2 \pm 1.56$} \\
\hline & \begin{tabular}{|c|}
14.33 \\
\pm 2.54 \\
\end{tabular} & \begin{tabular}{c|c|}
14.84 & 14.83 \\
\pm 4.03 & \pm 4.14
\end{tabular} & -1 & $\begin{array}{l}17.61 \\
+1.76 \\
\end{array}$ & - & $\begin{array}{r}9.41 \\
\pm 1.3 \\
\end{array}$ & $\begin{array}{c}8.88 \\
\pm 3.1 \\
\end{array}$ & $\mid \begin{array}{c}8.1 \\
\pm 2.8\end{array}$ & - & $\begin{array}{r}10.83 \\
\pm 1.76 \\
\end{array}$ & - \\
\hline \multirow{2}{*}{$6-10 \pm$} & \multicolumn{5}{|c|}{$14.6 \pm 3.44$} & \multicolumn{6}{|c|}{$8.59 \pm 2.24$} \\
\hline & \begin{tabular}{|r|}
14.7 \\
\pm 2.74 \\
\end{tabular} & $\begin{array}{l}16.0 \\
\pm 13.85 \\
\pm 1.28 \pm 3.42 \\
\end{array}$ & $\begin{array}{l}16.0 \\
\pm 4.86 \\
\end{array}$ & $\begin{array}{r}11.7 \\
\pm 2.62 \\
\end{array}$ & - & $\begin{array}{l}8.43 \\
\pm 0.95 \\
\end{array}$ & $\begin{array}{l}9.5 \\
\pm 0.64 \\
\end{array}$ & $\begin{array}{r}9.92 \\
\pm 1.59 \\
\end{array}$ & $\begin{array}{l}0.67 \\
\pm 3.36 \\
\end{array}$ & $\begin{array}{l}7.9 \\
\pm 0.98 \\
\end{array}$ & - \\
\hline \multirow{2}{*}{$11-15$ 才 } & \multicolumn{5}{|c|}{$16.6 \pm 2.48$} & \multicolumn{6}{|c|}{$10.07 \pm 1.97$} \\
\hline & $\begin{array}{r}16.5 \\
\pm 2.04 \\
\end{array}$ & $\begin{array}{l}18.75 \quad 17.25 \\
\pm 0.75 \quad \pm 3.06 \\
\end{array}$ & $\begin{array}{l}16.08 \\
\pm 2.17 \\
\end{array}$ & 18.0 & - & $\begin{array}{l}11.16 \\
\pm 2.69 \\
\end{array}$ & $\begin{array}{l}9.87 \\
+0.44 \\
\end{array}$ & $\begin{array}{r}10.0 \\
\pm 2.13\end{array}$ & $\begin{array}{l}9.62 \\
\pm 1.05 \\
\end{array}$ & 12.5 & - \\
\hline \multirow[b]{2}{*}{$16 一 20$ 才 } & \multicolumn{5}{|c|}{$14.46 \pm 3.36$} & \multicolumn{6}{|c|}{$9.0 \pm 1.6$} \\
\hline & $\begin{array}{l}10.42 \\
\pm 0.17\end{array}$ & $10.0 \begin{array}{c}17.91 \\
\pm 0.84\end{array}$ & $\begin{array}{l}16.18 \\
\pm 1.76\end{array}$ & - & - & $\begin{array}{l}7.6 \\
\pm 1.59\end{array}$ & 8.25 & $\begin{array}{r}10.41 \\
\pm 0.8\end{array}$ & $\begin{array}{l}0.18 \\
\pm 0.34\end{array}$ & - & - \\
\hline \multirow{2}{*}{$21-25$ 才 } & \multicolumn{5}{|c|}{$14.09 \pm 3.4$} & \multicolumn{6}{|c|}{$10.45 \pm 2.36$} \\
\hline & $\begin{array}{r}13.29 \\
\pm 3.69 \\
\end{array}$ & $\begin{array}{ll} & 12.25 \\
-\quad & \pm 0.75 \\
\end{array}$ & $\begin{array}{l}16.63 \\
\pm 0.37\end{array}$ & 16.75 & - & $\begin{array}{l}9.4 \\
\pm 2.46 \\
\end{array}$ & - & $\begin{array}{l}9.38 \\
\pm 0.87\end{array}$ & $\begin{array}{l}10.38 \\
\pm 0.1\end{array}$ & 12.25 & - \\
\hline \multirow[b]{2}{*}{67 北上 } & \multicolumn{5}{|c|}{$16.07 \pm 2.94$} & \multicolumn{6}{|c|}{$10 \cdot 29 \pm 0.75$} \\
\hline & $\begin{array}{r}16.22 \\
\pm 1.81\end{array}$ & $\begin{array}{c}15.6 \quad 15.93 \\
=2.03 \pm 3.63\end{array}$ & $\begin{array}{l}16.25 \\
\pm 3.11\end{array}$ & $\begin{array}{c}17.75 \\
\pm 1.0\end{array}$ & $\begin{array}{l}5.5 \\
\pm 0.5\end{array}$ & $\begin{array}{c}10.3 \\
\pm 1.72\end{array}$ & $\begin{array}{l}10.83 \\
\pm 1.16\end{array}$ & $\left\{\begin{array}{l}9.97 \\
-2.61\end{array}\right.$ & $\begin{array}{l}12.25 \\
+3.13 \\
\end{array}$ & $\begin{array}{c}11.38 \\
+1.81\end{array}$ & $\begin{array}{l}9.5 \\
\pm 0 \\
\end{array}$ \\
\hline
\end{tabular}

第 13 表 2

\begin{tabular}{|c|c|c|c|c|c|c|c|c|c|c|}
\hline $\begin{array}{l}\text { 学るこ鞍深 } \\
\text { 面 穔 }\end{array}$ & \multicolumn{10}{|c|}{$\mathrm{T}$} \\
\hline 年命区分 淀型 & & $\mathrm{SP}$ & & Rig. & SP & + Rig. & EX. & & Sch. & $\mathrm{N}$ \\
\hline \multirow{2}{*}{$0-5 才$} & \multicolumn{10}{|c|}{$7.32 \pm 1.22$} \\
\hline & 7.25 & \pm 1.7 & 6.5 & \pm 1.86 & 7.83 & \pm 1.4 & - & 7.75 & \pm 1.52 & - \\
\hline \multirow{2}{*}{$6-10 才$} & \multicolumn{10}{|c|}{$7.72 \pm 1.35$} \\
\hline & 8.0 & \pm 1.58 & 7.5 & \pm 0.64 & 8.0 & \pm 0.52 & $8.86 \pm 1.78$ & 7.7 & \pm 1.13 & - \\
\hline \multirow{2}{*}{$11-15 才$} & \multicolumn{10}{|c|}{$9.4 \pm 1.72$} \\
\hline & 10.06 & \pm 2.03 & 10.37 & \pm 0.5 & 8.5 & \pm 1.41 & $9.33 \pm 1.25$ & & 10.5 & - \\
\hline \multirow{2}{*}{$16-20 才$} & \multicolumn{10}{|c|}{$9.0 \pm 1.06$} \\
\hline & 8.75 & \pm 1.24 & & 8.0 & 9.66 & \pm 0.56 & $10.06 \pm 1.22$ & & - & - \\
\hline
\end{tabular}




\begin{tabular}{|c|c|c|c|c|c|c|}
\hline \multirow{2}{*}{$21-25$ 才 } & \multicolumn{6}{|c|}{$9.18 \pm 1.71$} \\
\hline & $9.91 \pm 2.04$ & - & $8.13 \pm 0.1$ & $8.87 \pm 1.89$ & 8.5 & - \\
\hline \multirow{2}{*}{26 才以上 } & \multicolumn{6}{|c|}{$9.14 \pm 2.18$} \\
\hline & $8.75 \pm 0.72$ & \multicolumn{2}{|c|}{$10.6 \pm 1.5710 .28 \pm 2.07$} & $8.0 \pm 1.97$ & $9.63 \pm 0.92$ & $10.5 \pm 2.0$ \\
\hline $\begin{array}{l}\text { そるこ鞍深 } \\
\text { 及面 積 }\end{array}$ & \multicolumn{6}{|c|}{$\mathrm{t}$} \\
\hline 年令区分 病型 & SP. & Rig. & SP.+Rig. & EX. & Sch. & $\mathrm{N}$ \\
\hline \multirow{2}{*}{$0-5 才$} & \multicolumn{6}{|c|}{$5.72 \pm 1.37$} \\
\hline & $5.58 \pm 1.62$ & $5.0 \pm 2.14$ & $5.9 \pm 1.65$ & 一 & $6.25 \pm 2.6$ & - \\
\hline \multirow{2}{*}{$6-10$ 皮 } & \multicolumn{6}{|c|}{$6.59 \pm 1.24$} \\
\hline & $6.86 \pm 1.35$ & $5.5 \pm 0.64$ & $6.0 \pm 0.52$ & $7.33 \pm 0.75$ & $6.5 \pm 0.85$ & \pm \\
\hline \multirow{2}{*}{$11-15$ 才 } & \multicolumn{6}{|c|}{$7.52 \pm 1.24$} \\
\hline & $8.75 \pm 1.27$ & $8.25 \pm 0.26$ & $7.16 \pm 0.90$ & $8.0 \pm 1.12$ & 8.5 & - \\
\hline \multirow{2}{*}{$16-20 才$} & \multicolumn{6}{|c|}{$6.27 \pm 1.42$} \\
\hline & $7.91 \pm 1.27$ & 6.0 & $8.08 \pm 0.26$ & $9.06 \pm 1.01$ & - & - \\
\hline \multirow{2}{*}{$21-25$ 才 } & \multicolumn{6}{|c|}{$7.72 \pm 1.47$} \\
\hline & $8.58 \pm 2.04$ & - & $6.63 \pm 0.37$ & $6.75 \pm 0.5$ & 7.5 & - \\
\hline \multirow{2}{*}{26 才以上 } & \multicolumn{6}{|c|}{$7.7 \pm 1.86$} \\
\hline & $7.52 \pm 2.01$ & $8.88 \pm 0.97$ & $8.25 \pm 1.19$ & $5.93 \pm 1.53$ & $8.38 \pm 0.31$ & $9.13 \pm 1.65$ \\
\hline $\begin{array}{c}\text { とるこ鞍深 } \\
\text { 及面 積 }\end{array}$ & & & 面 & 䅡 & & \\
\hline 年命区分 病型 & SP. & Rig. & SP. + Rig. & ES. & Sch. & $\mathrm{N}$ \\
\hline \multirow{2}{*}{$0-5$ 才 } & \multicolumn{6}{|c|}{$0.722 \pm 0.228$} \\
\hline & $0.75=0.25$ & $0.58 \pm 0.13$ & $0.76 \pm 0.16$ & - & $0.97 \pm 0.07$ & - \\
\hline \multirow{2}{*}{$6-10$ 才 } & \multicolumn{6}{|c|}{$0.768 \pm 0.255$} \\
\hline & $0.903 \pm 0.09$ & $0.906 \pm 0.127$ & $0.67 \pm 0.17$ & $0.775 \pm 0.365$ & 0.92 & - \\
\hline \multirow{2}{*}{$11-15$ 才 } & \multicolumn{6}{|c|}{$0.92 \pm 0.342$} \\
\hline & $1.08 \pm 0.08$ & 1.07 & $0.96 \pm 0.08$ & $0.876 \pm 0.135$ & - & - \\
\hline \multirow{2}{*}{$16-20$ 才 } & \multicolumn{6}{|c|}{$0.988 \pm 0.13$} \\
\hline & 0.82 & 0.9 & $1.06 \pm 0.191$ & $1.05 \pm 0.14$ & - & - \\
\hline \multirow{2}{*}{$21-25$ 才 } & \multicolumn{6}{|c|}{$1.035 \pm 0.297$} \\
\hline & $1.131 \pm 0.3$ & - & 0.816 & $0.94 \pm 0.24$ & 1.4 & - \\
\hline \multirow{2}{*}{26 才以上 } & & & & .085 & & \\
\hline & $1.016 \pm 0.277$ & $1.15 \pm 0.17$ & $1.081 \pm 0.302$ & $1.04 \pm 0.47$ & $1.015 \pm 0.132$ & $1.25 \pm 0.227$ \\
\hline
\end{tabular}


第 14 表

\begin{tabular}{|c|c|c|c|c|c|c|c|}
\hline 鞍背病型 & $\begin{array}{l}\text { 应直 } \\
\text { 型 }\end{array}$ & $\begin{array}{l}\text { 強剛 } \\
\text { 型 }\end{array}$ & 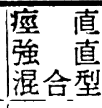 & \begin{tabular}{|l|} 
不随 \\
意運 \\
動型
\end{tabular} & 倠塄 & $\begin{array}{l}\text { 神経 } \\
\text { 症型 }\end{array}$ & 計 \\
\hline I 型 & 4 & 4 & 7 & 4 & 2 & 0 & 21 \\
\hline II 型 & 29 & 9 & 17 & 7 & 3 & 1 & 66 \\
\hline 【| 型 & 12 & 3 & 5 & 5 & 0 & 1 & 26 \\
\hline 計 & 45 & 16 & 29 & 16 & 5 & 2 & 113 \\
\hline
\end{tabular}

強渢型, 不随意運動型, 弛楥型, 神経症型の順となつ てある。第四型に属するものは, 痤直型が $46.1 \%$ で 最も多い。之を要するに, 各病型間の配列には特異性 は認め難いが, 痤直型の大半は第 II 型に属し, 第 II 型 に属するものには痤直型が多い様に思われる。

\section{4) 小括}

以上脳性麻㾇急者の頭蓋レ線像に現れた頭蓋縫合, 血管拝, 骨厚, 頭径, とるこ鞍について肉眼的観察, 計測值の結果を紊藤教授，伊藤博士の分類した六型に 分けて観察したのであるが，之を総括すると次の如く になる。

（i ）頭蓋縫合は，冠状縫合，人宇綎合共に痤直型 飞出現率高く, 不随意運動型飞少い結果となつてるる が，特に注目すべき各型間の特異性は認められない。

血管溝恰更特異な現れ方は認められない。

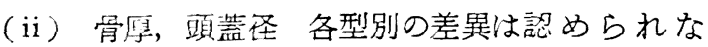
い。

（iii） とるこ鞍 1. 各经，面積の各型別の特異性 は誌められない。2. 䗆背の形態について言 5 と, 各 病型間の配列には特異性は認め難いが, 痤直型の大半 は第 II 型汇属し，第 II 型に属するものには痤直型が多 い様に思われる。

佐藤氏は，142 例の脳性麻瘏患者の Pneumoencephalogramm 飞就いて詳細なる研究を行い, 筇緊張を 坠体として分類した萮藤教授，伊藤博士の脳性麻痺六 型に就て,脳室の形態的観察, 計測的観察つ結果から, 各病型に於ける特有な脳室拡大の樣式の傾向がある事 を報告した。

私は脳性麻㾝患者の頭蓋骨にも脳室の変化と相関し た変化があるのではなからうかとの構想の下に各病型 別の比較検討を行つて見たのであるが，以上の様に何 等病型別の特異性を見出乙得なかつた。各病型に属す る症例が甚だ少数である為, 決定的な結論とする事が できないのは勿論で，向今後の研究に俟たねばならな いが，私の観察し得た範囲では，䏚性麻痷患者の頭蓋
レ線像には各病型間の特有の変化は䛊められなかつ た。

即ち臨床症状の相異を示す脳の障害部位の差も頭蓋 骨及とるこ鞍に対して一定の影鄉を与へるものではな いと思われる。

\section{結}

論

1）私は，脳性麻瘦患者 154 例の頭蓋骨レ線像に就 いて，肉眼的，計測的飞観察を行い，且之を斎藤教授， 伊藤博士の分類に依るの脳の障碍部位を異にすると考 へられる六型に分けて病型別観察を行つた。

2）脳性麻㾝患者の頭蓋綘合は，正常人と同様に一 般に年令の増加と共汇娍少する傾向が認められるが， 正常人よりも出現率ははるかに少い。この事は脳性麻 疩患者の頭蓋綘合が比較的早期淕合する事を意味 し,成書の記載と一致するもので興味ある事実である。

3）後頭隆起に就いては特に意義は附し難い。

4）イ）骨厚は確実に年令の増加に従つて大となつ てをり，且正常人のそれと略近い值を示してるるが， 16-20 才の間に於て急に発育の度を増す。

ロ）骨厚と脳圧との関䋆 脳圧の高い方が骨愿 は小である。

5）頭蓋佳は，11ー20午の間に特に急速な発育を示 す。

\section{6) とるこ鞍}

1) 各圣 成入では正常人と略同等か或は稍小な る值を示してるるが，発育過程から見る時は，11-15 才の間に最もよく発育する。

口）面積 各径と同じく 11-15 打の間に稍増大 の度を増す。

1)，口）の事実は正常者のとるこ鞍が $1-5$ 才の 間に最もよく発育すると云5先人の報告と異る点で注 目に值する。

7）とるこ鞍背の形態は，概ね三型に分類する事が できる。而して第II型て属するすのが過半数を占める。

8）脳性麻痺六型（斎藤教授，伊藤博士分類）飞就 いての各病型別観察結果は，各項目とも何等意義を附 すべき特異性は見出し難い。即ち, 臨床症状の相異を 示す脳の障害部位に影響されると思はれる様な一定の 変化を頭蓋骨及びとるこ鞍に於ては認める事ができな かつた。

本稿を終るに臨み，終始御想篤なる御指導を賜り， 御校閲を乔 うした恩師斎藤一男教授に深范なる謝意を 捧げ，種々御㪍示を与へられた伊藤講師，佐藤隆博士 飞深謝すると共飞御援助下さつた教室員一同に心から 
なる感謝の意を表する。

（本論文の一部は第2 24 回日本整形外科学会絵会飞於

て, 最近の我教室に於ける脳性麻疸研究の傾向と題し てその一部として伊藤講師が発表し，全文の要旨は第 26 回日本整形外科学会総会に於て発表した)。

\section{交献}

1) Aasmann : Klinische Röntgendiagnostik der inneren Krankheiten (1929)

2) Alblecht : Rontgenbefünd bei cerebralen Kalkherden, Mon f. Psy., 68 (1931)

3) Bokelmann : Fortschr, an d. Geb. d.R. (1932)

4) Brill : Vergleichende Messungen der sclla turcica in Kindesallers, Monschr. Kinderh., 57 (1933)

5) Camp: The sella turcica, the significance of chonfes in its roentgenophic appearance, Zbl. f. ges. N.u.P., 44 (1926)

6) Cignolini : Die Beziehungen $z w$. Hypophyse u. Röntgenbild des Turkensattels, Zbl. f. Ges. N.u. P. 55 (1930)

7) Cunha: Radiologie des Schädels, Speziell der Basis u. sella turcica, Zbl. f. Ges. N.u. P. 52 (1929)

8) Einfield : The normal sella, J. Amer. Med. Ass. (1922)

9) Erdélyi : Schädelverändelungen bei gesteigertem Hirndrŭck, Fortschr. a.d. Geb. d. Rönt., 4? (1930)

10) Goldhamer : Normale Anatomie des Kopfes im Röntgen-bild (1930)

11) Goldhamer u. Schüller : Die Variatäten der sella turcica, Fortschr. a.d. Geb. d.R., 33 (1925)

12) Haas: Erfahrungen auf dem Gebiete der radiologischen sella Diagnostik., Fortschr. Rontg., 33 (1925)

13) Paas: Verfahren zur sagittalen Aufnahme der Sellagegend, Fortschr. Rontg., 35 (1927)

14) Murphy: Intracranial calficication, Amer. J. R.a. Radth., 8 (1921)

15) Reinert : Beitrag zur röntgenologischen Selladiagnostik, Fortschr. a.d. Geb. d.R., 33 (1925)

16) Roth : Röntgenbild des Schädels bei gesteigertem Hirndruck, Klin. W., 1923 I

17) Schreiber : Intracranial pressure, the carrelation of chocked disc. and roentgenographic pressure signs, Am. J. Ront a. Radth., 23 (1930)
18) Steiert: ü.d. kindliche sellaturcica, ihre normale Entwicklŭng $u$. ihre Verhalten b. einer Reihe von abnormen Zuständen, Fortschr. a. d. Geb. d.R., 38 (1928)

19) Vastine : Pineale Body, Am. J. R. (1933)

20) Wieser : Die Patdologie der Hypophyse im Röntgenbilde (1925)

21）福沢：小巟媨疾患のれんとげん学的研究，日本 レ学会誌, 4,1 号

22）原：脳下垂体畽瘍の一例，日本レ学会誌，3, 3 号

23）平沢：脳及神径，第 1 号

24）伊藤：射創性晚発性廎瘤，臨床外科，2，4号

25）稲葉：とるこ鞍のレ線学的研究 (1), 金沢医理 学叢書, 6,39

26) 稲葉：とるこ鞍のレ線学的研究 (2), 金沢医理 学叢書, 6, 52

27）小枚：小児脳性麻瘦患児の頭形態に就て，児科 誌, 354 号

28）三田谷：児童の賢愚と身体との関係，神経誌， 17, 10 号

29）西岡：真正癭癎患者のるこ鞍のれんとげん的観 察, 日本レ学会誌, 6, 1 号

30）並木, 小枚, 馬島 : トルコ鞍レ線像撮影法に就 て,特にその面積測定亚にに Dorsumspitze $飞$ 就て, 皮泌科誌, 43, No. 1

31）中村：トルコ鞍のレ線定法，皮，性科誌，53, 5 号

32）中瀬：とるこ鞍像の臨床的意義，日本内科誌， 37, 1 号 12

33）齐藤, 伊藤：腷疾患と整形外科, 日整会誌，26， 6 号

34）佐藤：白痰及二三精神病者の頭覻特に頭蓋底の れえとげ兀像の所見，医学中央誌，15

35）佐藤：同上, 神経誌， 17

36）佐藤：䑈性麻瘦患者のPnermoencephalogramm に就て, 日医大誌, 17, 10 号

37）荘鳳：頭蓋底部のれんとげ兀映像，医学中央 誌, 20, 14 号

38）田宮：内科レントゲン診断学

39）田村：頭蓋描写図飞就て, 神経誌, 39

40）高木..とるこ鞍 線映像の研究,医事新聞,1091

41）種村：とるこ線鞍 X線像の研究, 医学中央誌, 28. 3

42）高山 $\cdots$ 外科, 11,4 号

43）宇田川, 高梨：とるこ鞍の発育亚に蝴蝶後頭骨 瘜合に関するれんとげん学的観祭，児科誌， 328 号

44) 宇田川, 高梨: 同上, 耳鼾咽喉科, 1, 3 号

45）安田：健康なる青年男子の頭径並びに其のれん とげん写真に顯れたるとるこ鞍の形態, 日本レ 学会誌, 3, 3 号 


\section{論交附図}

1. 杉 $\bigcirc$ 正 $\bigcirc$ 大 2 才

瘵直型

とるこ鞍型第 I 型

$\begin{array}{cccc}\text { be } & 15.75 & \text { ce } & 10.5 \\ \mathrm{~T} & 8.28 & \mathrm{t} & 6.75 \\ & & \end{array}$

骨厚 4.5 面積 0.933
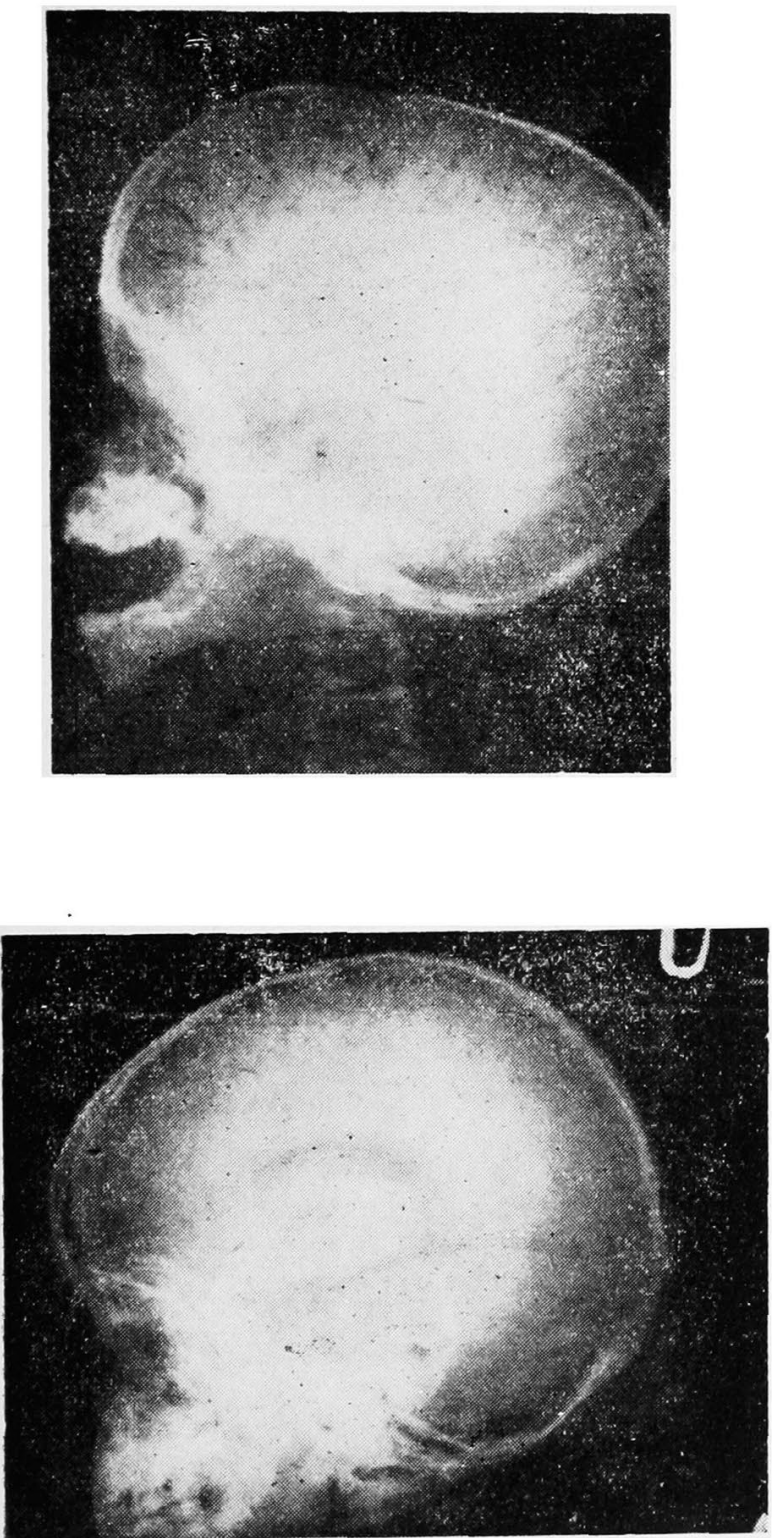

3. 神 $\bigcirc$ 考 $\bigcirc$ o 3 才

瘂直型脟圧 $200 \mathrm{~mm} / \mathrm{H}_{2} \mathrm{O}$ とるこ鞍型 第 II 型冠状維合 (-)
be
15.5
t $\quad 6.75$
ce 11.0
骨厚 $\quad 5.5$
T $\quad 8.25$
面積 0.9

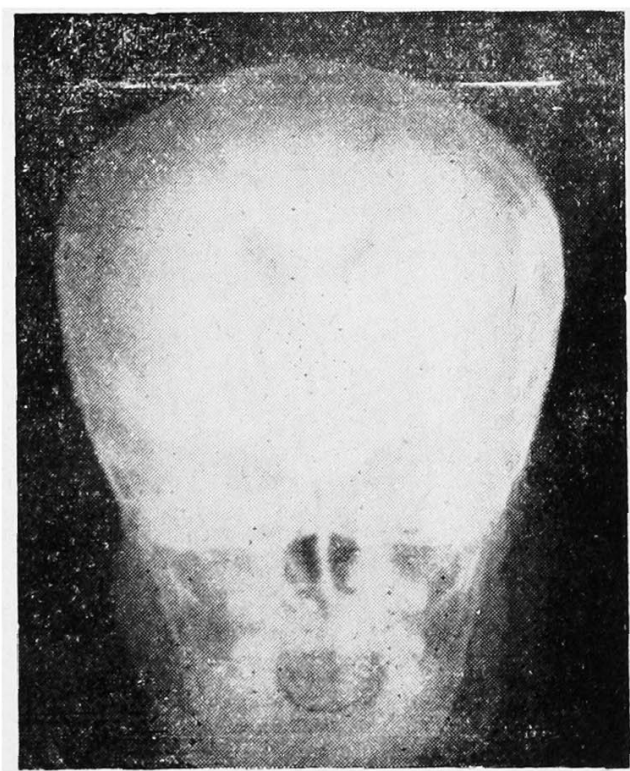

型

とるこ鞍型 第 II 型

$\begin{array}{rrrl}\text { be } & 17.5 & \text { ce } & 10.75 \\ \text { T } & 11.5 & \text { t } & 9.5\end{array}$

骨厚 2.5 面積 1.12

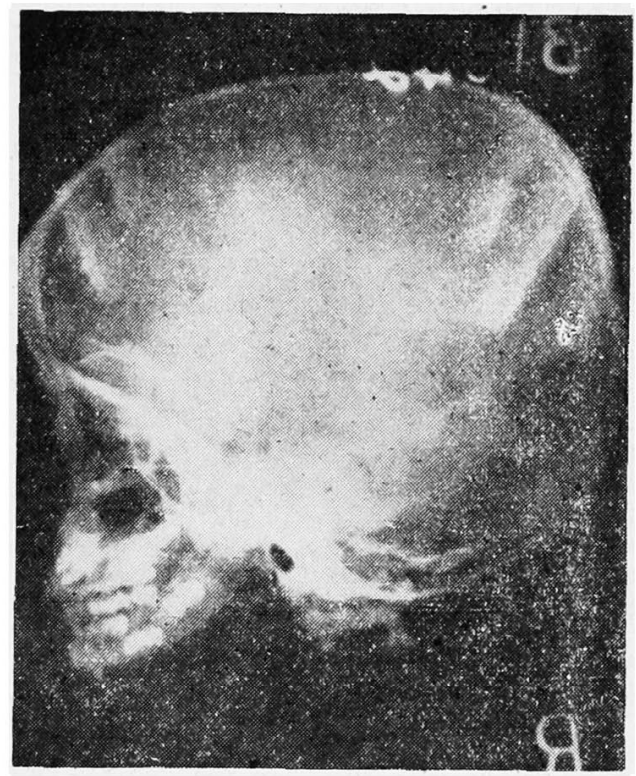


4. 杉 ○ 澄 $\bigcirc$ ㅇ 7 才

疗直型

$$
\begin{array}{lll}
\text { そるこ鞍型 } & \text { 第 II 型 } \\
\text { be } & 17.25 & \\
\text { ce } & 12.75 \\
\mathrm{~T} & 9.5 \\
\mathrm{t} & 8.0 \\
\text { 骨厚 } & 2.5 \\
\text { 面積 } & 1.28 \\
\text { 冠状, 人字縫合 (-) }
\end{array}
$$
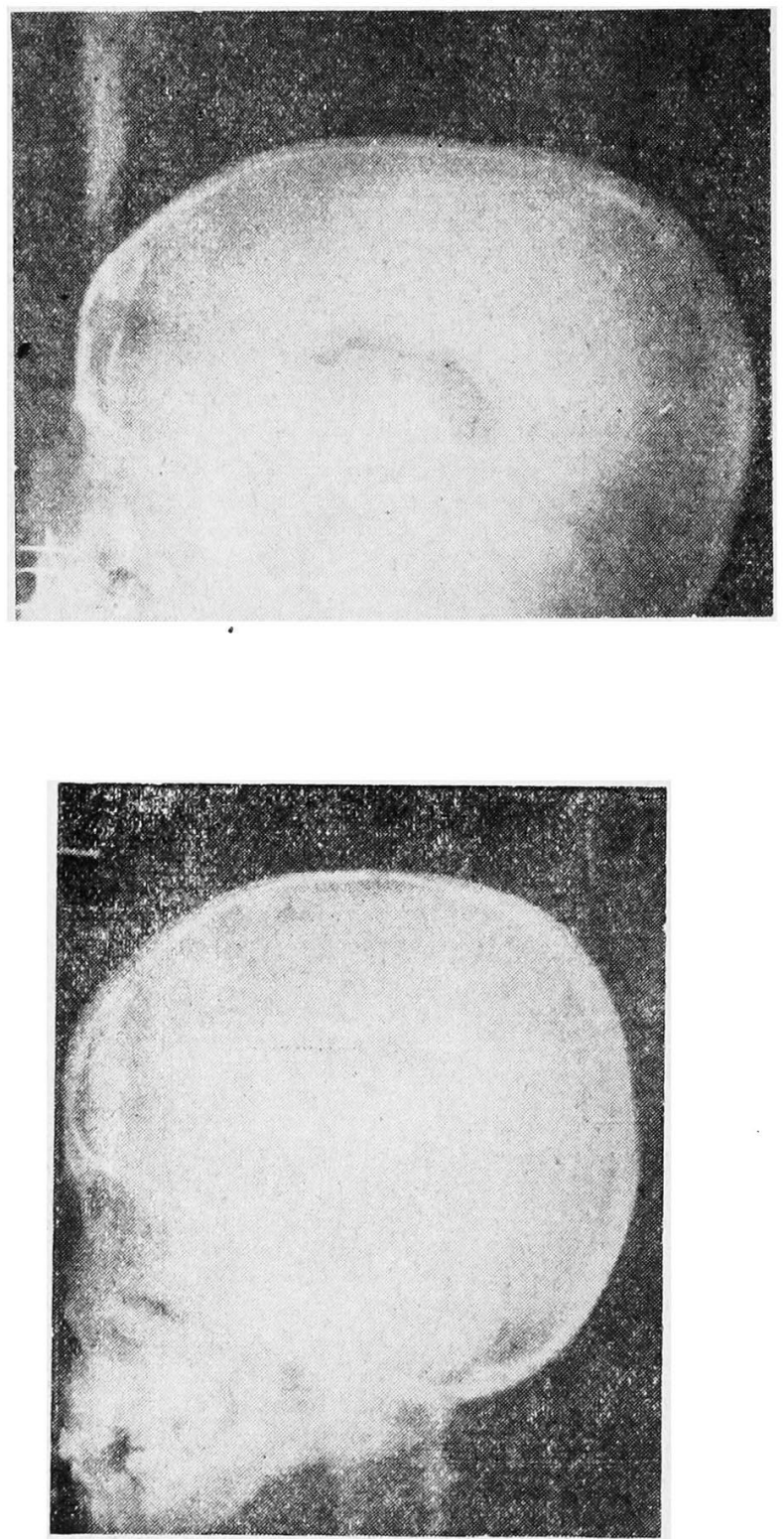

$$
\text { 5. 谷 } \bigcirc \text { 英 } \bigcirc \delta 10 \text { 才 }
$$

不随意運動型

とるこ鞍型 第】型
6. 坂 $\bigcirc$ 郁 $\bigcirc \quad$ 9 7 才

不随意運動型

とるこ鞍型 第 I 型

be 10.75 ce $\mathbf{5 . 5}$

$\begin{array}{llll}\text { T } & 6.5 & \text { t } & 6.0\end{array}$

骨厚 2.0 冠状, 人字䋖合( ( )
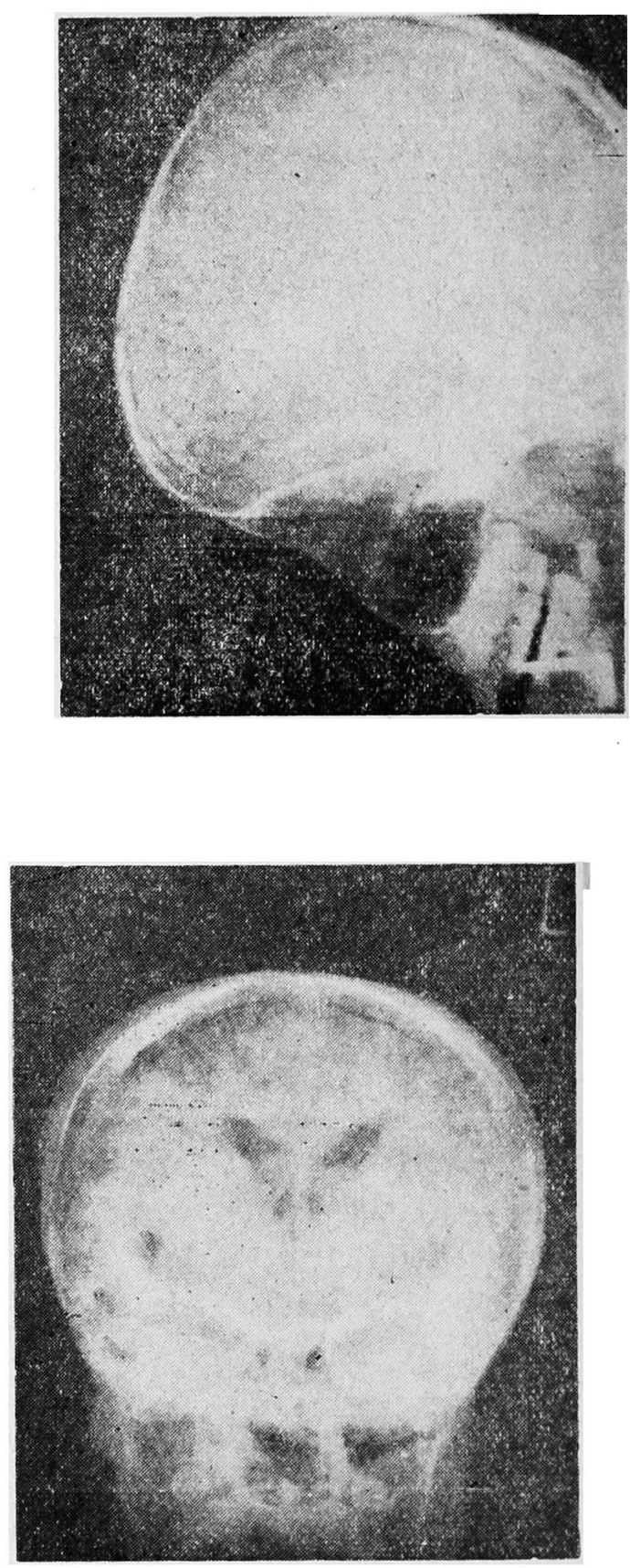

be $\quad 16.5$ 骨厚 5.0

ce 11.5 冠状, 人字繾合 (-)

T 10.5 遒圧 $200 \mathrm{~mm} / \mathrm{H}_{2} \mathrm{O}$

t $\quad 7.5$ 


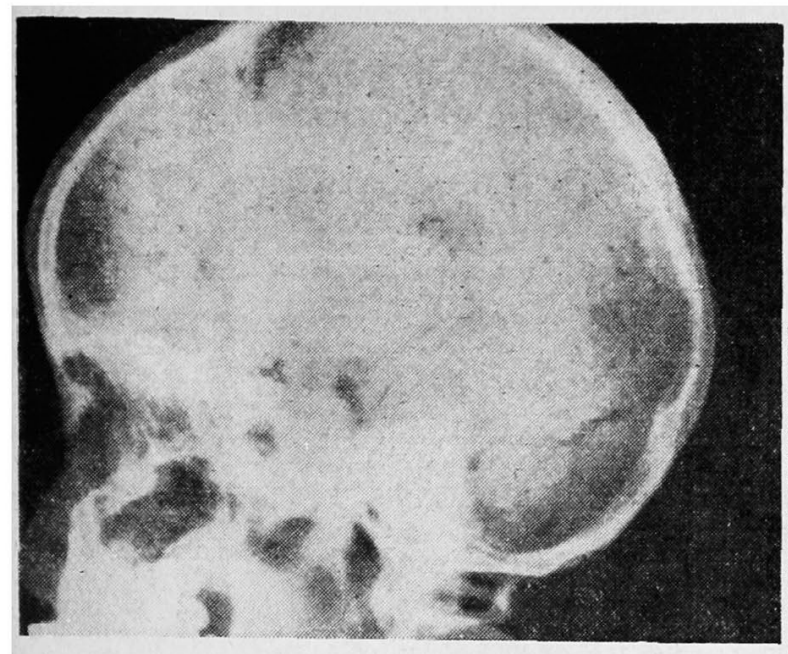
8. 稲 $\bigcirc$ 秀 $\bigcirc$ 令 16 才
瘥直强剛混合型
とるこ鞍第 III 型
be 18.25 ce 10.5
$\begin{array}{llll}\mathrm{T} & 9.25 & \mathrm{t} & 8.0\end{array}$
骨厚 6.0 面積 0.9
脳庄 $250 \mathrm{~mm} / \mathrm{H}_{2} \mathrm{O}$
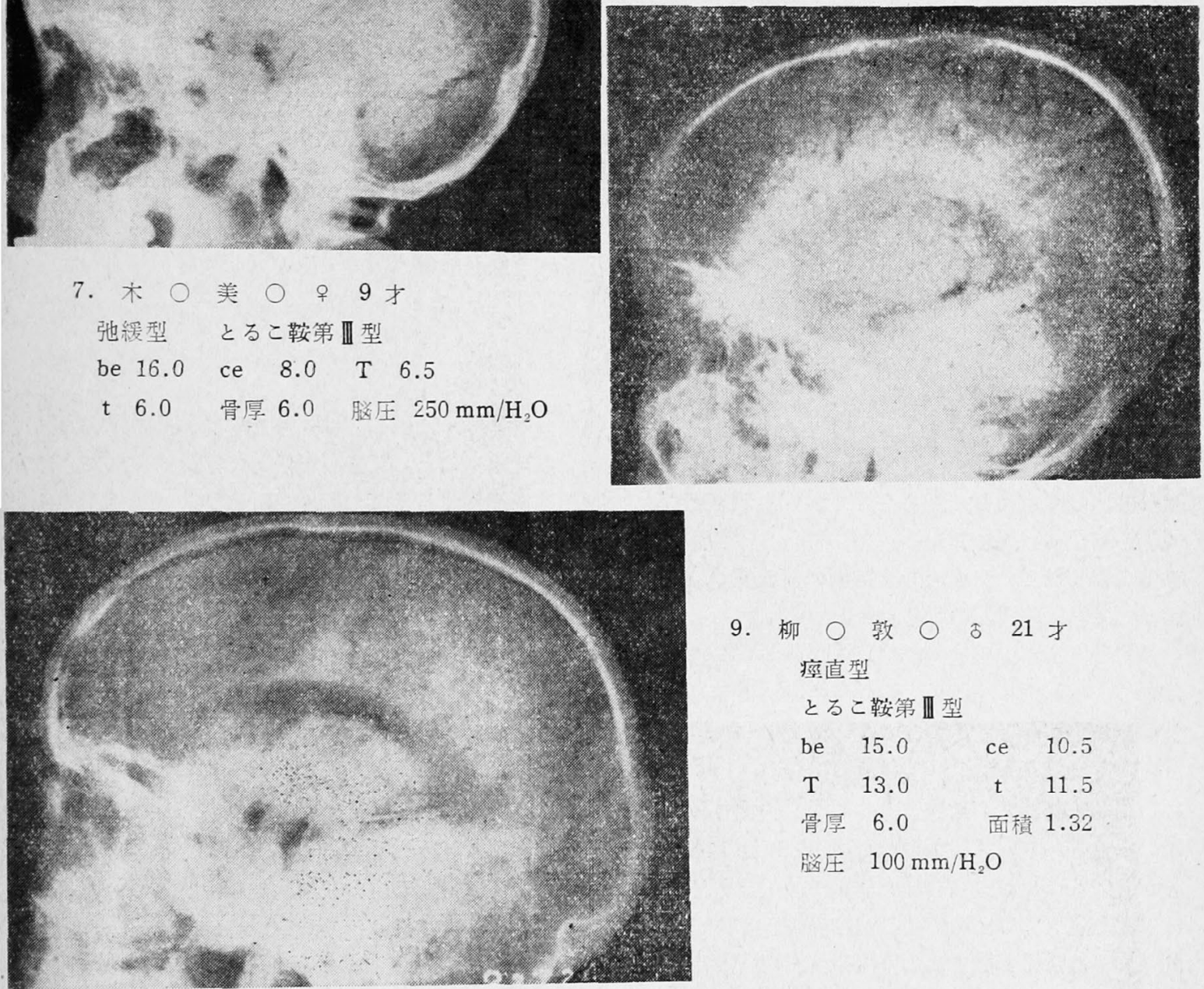

9. 柳 $\bigcirc$ 敦 $\bigcirc$ o 21 才

疗直型

とるこ鞍第 III 型

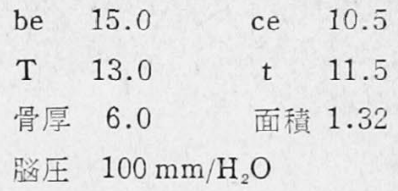

10. 米 $\bigcirc$ か $\bigcirc$ \& 57 才

疗苜型

とるこ鞍第 II 型

be 16.25 ce 8.75

T $5.75 \quad \mathrm{t} \quad 5.25$

骨厚 7.5

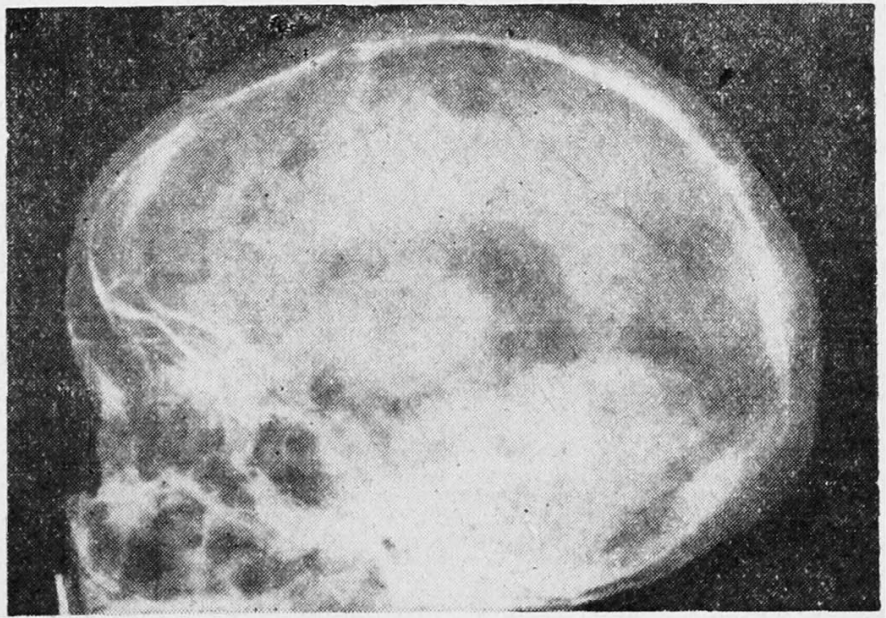

